
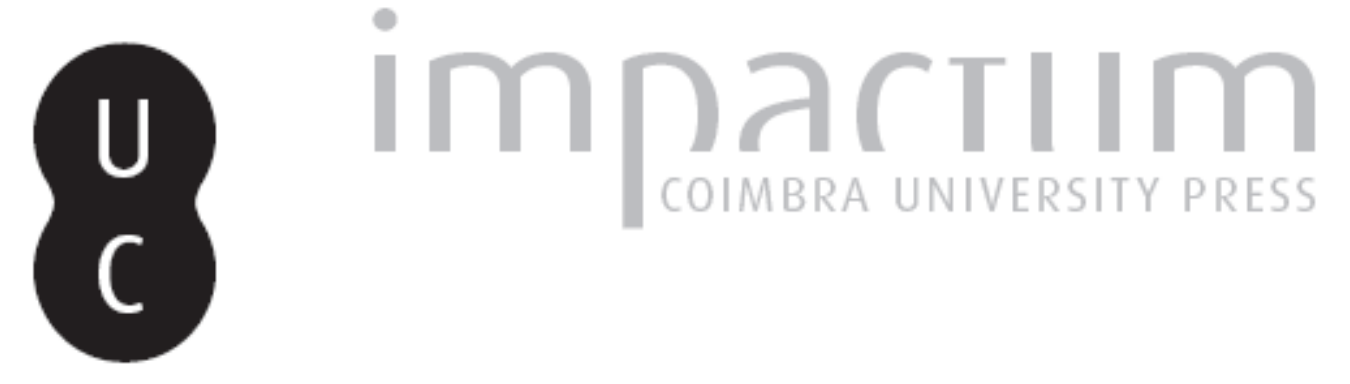

Clássicos, porém rebeldes: a recepção de Catulo na poesia ocidental

Autor(es): $\quad$ Castro Filho, Cláudio

Publicado por: Associação Portuguesa de Estudos Clássicos; Instituto de Estudos

Clássicos

URL

persistente:

URI:http://hdl.handle.net/10316.2/30409

DOI:

DOI:http://dx.doi.org/10.14195/0872-2110_52_18

Accessed : $\quad$ 26-Apr-2023 16:03:34

A navegação consulta e descarregamento dos títulos inseridos nas Bibliotecas Digitais UC Digitalis, UC Pombalina e UC Impactum, pressupõem a aceitação plena e sem reservas dos Termos e Condições de Uso destas Bibliotecas Digitais, disponíveis em https://digitalis.uc.pt/pt-pt/termos.

Conforme exposto nos referidos Termos e Condições de Uso, o descarregamento de títulos de acesso restrito requer uma licença válida de autorização devendo o utilizador aceder ao(s) documento(s) a partir de um endereço de IP da instituição detentora da supramencionada licença.

Ao utilizador é apenas permitido o descarregamento para uso pessoal, pelo que o emprego do(s) título(s) descarregado(s) para outro fim, designadamente comercial, carece de autorização do respetivo autor ou editor da obra.

Na medida em que todas as obras da UC Digitalis se encontram protegidas pelo Código do Direito de Autor e Direitos Conexos e demais legislação aplicável, toda a cópia, parcial ou total, deste documento, nos casos em que é legalmente admitida, deverá conter ou fazer-se acompanhar por este aviso.

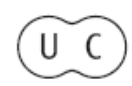




\section{Boletim de}

\section{Estudos Clássicos}

Associação Portuguesa de Estudos Clássicos Instituto de Estudos Clássicos

Coimbra

Dezembro de 2009 


\section{CLÁSSICOS, PORÉM REBELDES: A RECEPÇÃo de CATUlo NA POESIA OCIDENTAL}

"Eu não canto a defesa de Stalingrado / nem a campanha do Egito / nem o desembarque da Sicília / nem o cruzamento do Reno pelo general Eisenhawer: / Eu só canto a conquista de uma moça”. Estes versos, do nicaraguense Ernesto Cardenal, homenageiam Calímaco (século III a.C.) poeta grego que, ao se rebelar contra a poesia épica, deu passagem a toda uma tradição elegíaca. É este agudo sentimento de conjuração lírica que trespassa "Fogo Alto", antologia de poemas organizada e traduzida por Afonso Henriques Neto, editada no Rio de Janeiro pela casa Azougue.

O livro reúne nomes há tempos inscritos entre os grandes da poesia ocidental. Mas seus lugares no panteão literário foram conquistados a duras penas, no que pese o caráter transgressor de suas escritas, a pôr em jogo a problemática relação entre poder e poesia. Neste embate, a história demonstra que ao governante é preciso impor-se ao bardo: ou o poeta canta os grandes feitos do poder ou é necessário bani-lo, como sugeriu Platão em seu mais conhecido tratado filosófico.

O primeiro dos banidos rememorado por Henriques Neto é o latino Catulo (século I a.C.), de quem se conhece pouco mais de cem poemas. Recusando a monumentalidade da epopeia, Catulo manteve a temática alusiva (ou seja, o uso de personagens) da tradição homérica, mas herdou a lírica amorosa de Safo de Lesbos (século VII a.C.), assim traduzida e laureada pelo romano: "desde que te vi, Lésbia, nada restou / de voz em minha boca, / a língua se me entorpece, uma tênue chama / percorre os membros, das próprias vibrações / os ouvidos retinem, dupla noite / cobre-me os olhos”.

François Villon, nascido em 1431, é o segundo poeta contemplado em “Fogo Alto”. Embora diplomado pela Universidade de Paris, Villon entregouse errantemente à existência e à poesia. Na vida, suas atribulações chegaram à gravidade de assassinar um padre, crime perdoado. Na arte, desvirtuou com acidez os temas da poesia de seu tempo, em boa parte comprometida com o maniqueísmo medieval. O resultado é uma escrita "sem ilusões”, satírica e visceral. Condenado à morte, compôs: “A carne que engolia tanto alimento, / 
Hoje, roída, é apodrecimento. / E - ossos - cinza e pó já vamos ser. / (...) Mas rogai a Deus para nos absolver!”.

Atravessando o Canal da Mancha, a antologia volta-se para o londrino William Blake (1757-1827), que, ao contrário de Villon, trilha um caminho à margem da erudição. Blake deixa-se contaminar pelo ocultismo de Paracelso, imaginando a poesia e o cosmos sob a ótica alquímica: "Ver o Mundo em um simples grão, / Todo o Céu nesta flor do campo, / Reter o Infinito na palma da mão / E a eternidade em um relâmpago".

Numa volta a Paris, encontra-se a pólvora de Rimbaud (1854-1891), para quem "o poeta é realmente o ladrão do fogo". Sua poesia, realizada entre os 15 e os 20 anos, agrega sofisticadas referências míticas (como as metáforas afrodisíacas) a uma escrita apocalíptica, que (em paralelo a Nietzsche) condena a moral e proclama o desregramento dos sentidos: "com o infinito amor na alma que tudo quer, / vou longe, muito longe”.

É preciso recobrar o fôlego para assomar-se à poética em língua espanhola, representada pelas obras do chileno Vicente Huidobro (18931948) e do espanhol Federico García Lorca (1898-1936). Pablo Neruda (1904-1973) merece ser lembrado como o elo que congrega e, ao mesmo tempo, distingue Huidobro e Lorca. Do primeiro, Neruda foi adversário político, o que não o impediu de considerá-lo uma influência em sua própria poesia: "Admirava profundamente Huidobro, e dizer profundamente é dizer pouco”, confessou. De Lorca, por outro lado, Neruda foi incondicional amigo e colaborador - chegaram até a escrever a quatro mãos.

A antologia revela um Huidobro que, entusiasmado pelo ultraísmo das primeiras décadas do século $\mathrm{XX}$, entregou-se ao delírio poético: "Cai a noite buscando seu coração no oceano”. Quanto a Lorca, o livro traz poemas emblemáticos de seus últimos anos, destacando tanto seu viés surreal quanto sua reinvenção de poéticas consagradas. Retomando a tradição clássica dos cantos fúnebres, Lorca chora, às cinco da tarde, a morte do amigo toureiro: "Dize à lua que não venha, / que não quero ver o sangue / de Ignacio por sobre a areia".

O estadunidense Allen Ginsberg (1926-1997), ícone da underground cultura beat, encerra a antologia com uma escrita de fortes atitudes política e estética. Nesta leitura, Ginsberg trafega entre o apolíneo de sua exemplar formação intelectual e o dionisíaco de sua pena anárquica: “duvido que mais alguém venha a cair alguma vez a não ser os governos / felizmente todos os governos cairão / os únicos que não cairão serão os bons / mas os bons governos ainda não existem”. 
Ao reconhecer o parentesco espiritual entre autores de universos poéticos tão singulares, "Fogo Alto” lança um olhar desconstrutor sobre a tradição poética ocidental. Nesta perspectiva, cantam em coro as vozes de rebeldes que viveram - na carne e na palavra - os trágicos (des)limites entre amor, poesia, morte e liberdade. É o que se lê no "Poema duplo do lago Edem”, de García Lorca:

“Quero chorar porque me dá gana como choram os meninos do último banco, porque não sou um homem, nem um poeta, nem uma folha, mas sim um pulso ferido que sonda as coisas do outro lado.

(...)

Não, não, eu não pergunto, eu desejo, voz minha libertada que me lambes as mãos.

No labirinto de biombos é minha nudez que recebe a lua de castigo e o relógio em cinzas soterrado.”

\section{Referência}

Henriques Neto, Afonso (org.), Fogo Alto: Catulo, Villon, Blake, Rimbaud, Huidobro, Lorca, Ginsberg, Rio de Janeiro, editora Azougue, 223 páginas. 